\title{
XXXIII. Notes on the geographical distribution of organic remains contained in the oolitic series of the Great London and Paris Basin, and in the same series of the South of France
}

\section{Henry T. De la Beche F.R.S.}

To cite this article: Henry T. De la Beche F.R.S. (1830) XXXIII. Notes on the geographical distribution of organic remains contained in the oolitic series of the Great London and Paris Basin, and in the same series of the South of France , Philosophical Magazine Series 2, 8:45, 208-213, DOI: $10.1080 / 14786443008675406$

To link to this article: http://dx.doi.org/10.1080/14786443008675406

曲 Published online: 13 Jul 2009.

Submit your article to this journal

Џ Article views: 5

Q View related articles $\longleftarrow$ 


\section{[ 208$]$}

XXXIII. Notes on the Geographical Distribution of Organic Remains contained in the Oolitic Series of the Great London and Paris Basin, and in the same Series of the South of France. By Hen ry T. De la Beche, F.R.S. \& c.

[Concluded from p. 44.]

\section{Annulosa.}

1. Vermicularia compressa (Y.\&B.). Coral oolite, and inferior oolite. Yorks. (Phil.).

2. - nodus (Phil.). Cornbrash and great oolite. Yorks. (Phil.).

1. Serpula squamosa (Bean). Coral oolite. Yorks. (Phil.).

2. - lacerata (Phil.). Calc. grit, and great oolite. Yorks. (Phil.).

3. - intestinalis (Phil.). Oxford clay and cornbrash. Yorks. (Phil.).

4. - - deplexa (Bean). Inf. oolite. Yorks. (Phil.).

5. - capita (Phil.). Lias. Yorks. (Phil.).

6. — triquetra. Inf. oolite. Mid. and S. Engl. (Conyb.).

7. —_ quadrangularis. Oxford clay. Normandy (Desn.).

8. - - sulcata (Sow.). Calc. grit. Oxford (Sow.).

9. _- tricarinata (Sow.) Calc. grit. Oxford. Coral rag. Steeple Ashton, Wilts. (Sow.).

10. - - triangulata (Sow.). Bradf. clay or great oolite. Bradford (Sow.).

11. _- runcinata (Sow.). Coral rag. Oxford (Sow.).

- species undetermined. Coral rag, Oxford clay, cornb., forest marb., Brad. clay, great oolite. Mid. and S. Engl. (Conyb.). Brad. clay.

1. Dentalium giganteum (Phil.). Lias. Yorks. (Phil.).

2. cylindricum (Sow.): Lias. Mid. and S. Engl. (Conyb.).

Dentalium, species undetermined. Calc. grit. Yorks. (Pbil.).

\section{Summary of the foregoing List.}

Mammalia: Didelphys, 1 species. Reptinia: Pterodactylus, 1 species, and probably another; Crocodilidæ, 5 species, and probably others; Megalosaurus, 1 ; Geosaurus, 1; Plesiosaurus, 5, one being questionable; Ichthyosaurus, 4, and probably others; Testudinata, species undetermined. INSecra : Coleopterous. Pisces : I species, and many others not determined; Ichthyodorulites, or fish spears; palates, teeth, \&c. Crustacra: Astacus 1; many other crustaceous remains undetermined. Zoophyta: Spongia, 1 , and probably others; Alcyonium, species not determined; Turbinolia, I, and others not determined; Turbinolopsis, 1; Entalophora, 1; Limnorea, 1; Caryophyllia, 7, and others; Millepora, 6; Favosites, species not determined; Astrea, 6; Cellepora, species not determined; Fungia, 1, and probably others; Spiropora, 4; Eunomia, 1, and probably others; Cyclolites, 1 ; Chrysaora, 2; Theonoa, 1 ; Idmonea, 1 ; Alecto, 1, and probably others; Berenicea, 1 ; Terebellaria, 2; Retipora? Cellaria, 1 ; Thamnasteria, 1 ; Explanaria, 1 ; Madrepora, Meandrina, 
drina, and Eschara, species not determined; remains of other Polypifers, genera doubtful.

\section{RADIARIA.}

Cidaris, 9; Echinus, 1, and probably others; Clypeus, 6; Spatangus, 1; Clypeaster, 1; Galerites, 2; Ananchites, 1; Nucleolites, 2; and numerous Echinital remains of undetermined genera; Asteria, species not determined; Ophiura, 1 ; Apiocrinites, 2; Pentacrinites, 6; and Crinoidal remains, genera not stated.

CONCHIFERA AND MOLLUSCA.

Pholas, 2, one questionable; Pholadomya, 16 ; Panopæa, 2; Mya, 7; Sanguinolaria, 2; Crassina, 7; Amphidesna, 5; Lutraria, 1; Gastrochæna, 1; Psammobia, 1; Lucina, 3; Unio, 7; Pullastra, 2; Venus, species not stated; Cytherea, 1; Corbis, 2; Tellina, 1; Astarte, 12; Corbula, 4, one questionable; Cardium, 11; Isocardia, 6; Cardita, 3; Trigonia, 12; Hippopodium, 1; Nucula, 9; Cucullæa, 13; Arca, 3; Pectunculus, 2 ; Crenatula, I ; Inoceramus, I ; Modiola, 16 ; Mytilus, 5; Trigonellites, 2; Mactra, 1; Pinna,7; Perna, 1; Gervillia, 7; Avicula, 11; Plagiostoma, 17; Pecten, 20; Lima, 4; Exogyra, 1; Chama, 2; Plicatula, 1; Ostrea, 23; Gryphæa, 14; Lingula, 1; Terebratula, 45; Spirifer, 1 ; Donacites, 1; Cyclas and Lithodomus, species undetermined; Orbicula, 3, one questionable; Delphinula, species not stated; Natica, 5; Turbo, 9; Trochus, 21 ; Turritella, 4 ; Myoconcha, 1; Terebra, 4; Ancilla, species undetermined; Emarginula, 1; Patella, 6; Rissoa, 4; Melania, 4; Bulla, 1 ; Murex, 1 ; Cirrus, 4 ; Actæon, 5 ; Nerinea, species undetermined ; Pteroceras, 3; Rostellaria, 4; Phasianella, 1; Solarium, 2; Nerita, 4; Buccinum, 1 ; Auricula, 1; Planorbis, 1; Helicina, 4 ; Tornatella and Ampullaria, species undetermined; Belemnites, 12, and most probably others; Orthoceras, 1 ; Turrilites, 1; Nautilus, 10, and probably others; Ammonites, 114.

\section{ANNUE.OSA.}

Vermicularia, 2; Serpula, 11; Dentalium, 2.

VEGETABLE REMAINS.

Fucoides, 1 species; Equisetum, 1; Pachypteris, 2; Pecopteris, 6; Sphænopteris, 5 ; Tæniopteris, 2 ; Pterophyllum, 1 ; Zamia, 11 ; Zamites, 4 ; Thuytes, 4 ; Taxites, 1.

Upon a review of the above lists, it will, I think, be observed that our knowledge of the vegetable remains is too limited to enable us to form any general conclusions respecting them. Mammalia have been only observed in one locality, Stonesfield. N. S. Vol. 8. No. 4.5. Sept. 1830. 


\section{$210 \mathrm{Mr}$. De la Beche on the Geographical Distribution of Organic}

Of Pterodactyles our knowledge is limited. Crocodiles seem to have existed during the whole deposit of the oolite, and to have been widely distributed; the same may be said of the Ichthyosnurus and the Plesiosaurus. Neither Pterodactyles, Crocodiles, Ichthyosauri, nor Plesiosauri, have yet been observed in the South of France. The Geosaurus has at present only been noticed in the lias of Wurtemberg, and the Megalosaurus in the Stonesfield slate, near Oxford, and in the great oolite of Normandy*. Respecting Tortoises, Turtles, and Fish, we do not possess information that can lead to any useful conclusions. Insects are yet known only in the oolite at Stonesfield. Polypifers occur in considerable abundance in particular places, and, as it would appear, principally in the oolite that has been thence named Coral rag, and in the upper part of the great oolite, which has thence obtained the name of Calcaire a Polypiers in Normandy. It has been imagined that the coral rag is a constant rock in the oolitic series; which is supposing that during the deposition of the oolite there was a time when the whole bottom of the sea was covered by an universal coral reef, and that the same polypifers could exist under varions pressures of water; suppositions that are at variance with the habits of existing polypifers. When polypifers do however occur in any abundance, they have been observed in the strata above noticed, in both cases accompanied by remains of the genera Clypeus and Cidaris. By reference to the above lists, it will be also observed that several shells are common to the coral rag and great oolite. The Crinoidal remains contained in the oolite appear principally Pentacrinites and Apiocrinites; the former occurring abundantly and widely distributed in the lias; the latter in the great oolite, or its accompanying beds, the cornbrash, forest marble, or Bradford clay.

Of the Conchiferous and Molluscous remains entombed in the oolite, 540 species have, according to the foregoing list, been determined; of these 114 (more than one-fifth) are Ammonites, which are not only abundant as species, but as individuals, so that some beds are almost wholly composed of them. The great abundance of Ammonites and Belemnites may be stated as a great characteristic of the oolitic series : they are particularly numerous in the lias.

As far as our knowledge of the organic characters of European rocks at present extends, the shells contained in the ooli-

- Dr. Buckland informs me that in the year 1826 he recognised many bones of the Megalosaurus in the museum of Besancon from the oolite of that neighbourhood. 
tic series, though frequently not confined to particular portions of that series, even in England and France, still seem as a mass characteristic of it within the limits noticed in this memoir. The following shells, according to the foregoing list, contained in the oolite, have been noticed in the chalk and green sand:

1. Terebratula subrotunda. Chalk. Sussex (Mantell).

2. - carnea. Chalk. Suss. (Mant.). Chalk. Paris and Normandy (Al. Brong.).

3. - ovata. Chalk and green sand. Suss. (Mant.).

4. - biplicata. Green sand, Suss. (Mant.).

5. —— lata. Green sand. Suss. (Mant.).

6. - ornithocephala. Green sand. Perte du Rhone, Fis (Al. Brong.).

1. Gervillia aviculoides. Green sand. Suss. (Mant.).

2. - acuta. Green sand. Suss. (Mant.).

1. Cucullæ decussata. Chalk marl. Suss. (Mant.). Chalk marl. Rouen (Al. Brong.).

I. Turbo rotundatus. Green sand. Blackdown (Suw.).

1. Rostellaria Parkinsoni. R. Sowerbii (Mant.). Green sand. Blackdown. (Sow.). Suss. (Mant.).

1. Ammonites splendens. Gault. Suss. (Mant.)

2. - levigatus. Gault. Suss. (Mant.).

1. Cirrus depressus. Chalh. Suss. (Mant.).

1. Exogyra digitata. Green sand. Lyme Regis, abundant (De la B.).

1. Mya mandibulata*. Green sand. Devizes and Lyme Regis.

Whether we are to conclude that the same species occur in the cretaceous and oolitic groups depends on the credit we may consider due to the respective authors cited; in fact, to their ability in determining specific differences;-no easy task, but I do not see why, with our present limited knowledge, we should determine the question without further examination.

It has been generally supposed that the rocks of the oolitic series have been deposited in a sea; and the great abundance and proportion of marine organic remains entombed in them would seem to render this supposition probable. We have no data by which to form any conception of the extent of such a sea. The portion of the world occupied by the oolitic rocks, noticed in the foregoing remarks, is of insignificant extent, comprised within a few degrees of latitude and longitude. How far the oolitic series may hereafter be found to extend, it would be difficult to say. It is possible that it may merge in some other great rock deposit, or even be considerably developed at the expense of the cretaceous rocks above or the red sandstone rocks beneath.

It will be remarked that terrestrial plants, lignite, or coal, occur more or less throughout the whole series. May we not

* Supposed to be Mya mandibula of Sowerby. 


\section{Mr. De la Beche on the Distribution of Organic Remains.}

therefore conclude that dry land existed in, or not far distant from, the eomparatively small space containing the organic remains enumerated in the foregoing table? The principal deposits of carbonaceous matter would seem to be Brora and Yorkshire.

Most of the great Saurians now buried in the oolite would seem also to have required the protection of land; for though the Ichthyosauri might, like the Porpesse, brave the waves of an ocean, the structure of the Plesiosauri would seem to unfit them for such exposure; and, judging from the habits of modern crocodiles, the ancient species are not likely, from choice, to have quitted the neighbourhood of land. The Pterodactyles probably flew over the land, and the Didelphys must have lived upon it.

The quantity of corals contained in the forest marble, great oolite, or coral rag, would seem to show that the places, where these remains are the most abundant, must have had a comparatively shallow covering of water at the time these Zoophytes existed.

The evidence, therefore, would seem to be in favour of a comparatively shallow sea, interspersed with dry land, for the formation of so much of the rocks usually termed oolitic, as occur within the space treated of in these notes. The great abundance of Oysters and Gryphites may probably also be in favour of comparatively shallow water*.

I have been thus particular in enumerating what may appear to be evidence of comparatively shallow seas, because the same deposit may have been, and probably was, going on in contiguous and deeper portions of the ocean, and because these continuous portions of the same formation may differ very considerably both in mineralogical and organic character. Thus the oolitic series of England and of France may be represented even so near as Italy and Greece, by a series of beds so different in organic contents, as at first sight to be considered distinct.

Endeavours to trace the small divisions into which the oolitic series of England has been separated, are no doubt useful if our attention be directed to an examination of the areas over which certain minor causes may have operated: but when these small

* It is remarkable that the three great argillaceous deposits of the oolitic series contain an abundance of either Gryphites or Oysters, and that the Saurian remains are most commonly observed in the same strata. Thus the Ostrea deltoidea in England, and the Gryphæa virgula in France, have been termed characteristic of the Kimmeridge clay; the Gryphæa dilatata is a common shell in the Oxford clay; and the Gryphaa incurva Sow. (G. arcuata $L a m$;) is abundant in the lias. 
divisions are supposed to be general, and geologists expect to meet with cornbrash in China, much mischief ensues, and much valuable time and talent is wasted in endeavours to prove that the whole surface of the world is minutely the same as any given quarry, province, or even kingdom.

It does not seem irrational to infer that such minute divisions, characterised by peculiar fossils, can only be traced over comparatively small areas, unless we are to suppose that the same animals and vegetables existed over the whole surface of the globe at the same time,- that these were suddenly destroyed -imbedded 10,20,100, or 400 feet deep, as the case might be, -that then there was a new creation,-then a total destruction, and so on.

So far as respects the limited area of which we have been treating, there do appear to have been certain general or nearly similar causes in operation. Consequently, though many species of shells \&c. are not strictly confined within the small limits usually assigned them, still in the oolitic series taken as a mass there would appear to be a general resemblance in organic character.

Belemnites seem to have been equally abundant in the lower parts of the series everywhere. The Gryphæa incurva is found under similar circumstances in Scotland, England, and France; and the same may be said of many other shells. Ichthyosauri of the same species occur in similar situations in Germany, England, and the North of France.

It therefore would appear that, during the deposit of the oolitic series, the geographical distribution of the animals, whose remains we now find entombed in its various beds, was not widely different throughout the area treated of in these Notes, It also would appear, although some animals may have existed in one place and not in another, and although these remains may occur in various beds in one locality and be confined to one bed in another, that the organic character of the mass is similar in Scotland, England, and France.

XXXIV. On the Economy of the Steam-Engine, and on some very general Mistakes regarding the Expansions of MM. Dulong and Petit. By Henky Meikle, Esq.

Sir, To Richard Taylor, Esq.

FROM looking into the Quarterly Journal of Science for January-March, 1830, page 186, I observe that Mr. Ainger, who some time ago showed such a laudable zeal in claiming 